\title{
Alternatively the Role of Parents
}

KEY WORDS

sexuality, homosexuality, family, G/L family

\begin{abstract}
Smetanová Dorota, Alternatively the Role of Parents [Alternatywna rola rodziców]. Kultura - Społeczeństwo - Edukacja nr 1 (3) 2013, Poznań 2013, pp. 183-190, Adam Mickiewicz University Press. ISBN 978-83-232-2631-4. ISSN 2300-0422

Topic of homosexuality is gradually coming to consciousness (not only) in Slovak society and it also due to the many professional works, which after the political changes in the last decade in our country gradually emerge from the depths of the taboo spheres to the spheres of ideological confrontations and constructive discussions. We do not claim that our society has reached the necessary level of debate both groups, heterosexual majority and gay and lesbian minority. However, took a path whose goal has signs of democratic society. All new phenomena must strike a long way till they are completely understated, accepted by society and at last integrated to the common life of society. Homosexuality is such a phenomenon. This path is a test of endurance gays and lesbians and heterosexuals test of democratic thinking. The contribution we tried to transmit a little further from the general question of homosexuality, specifically one of the areas described below, which is an area of "presence" of the child in the gay and lesbian partnerships.
\end{abstract}

We realize that the relationship with the child may be manifested in different ways. And whether it has already been done intentionally or unintentionally, it is the decisive factor of its development, determines the course of his childhood, often with lifelong consequences. In other words, we - with our attitudes and our behavior - are the chance, boon, but also a threat or disaster for our child.

(Z. Helus, 2004, s. 219).

Currently there is still a big influence of various institutions (state, church, family) that suppress the individualization and diversity of individual lifestyles. They dictate strong social framework, violation of which is punishable or identified as pathological, sick, or inappropriate. If an individual leaves the „standards”, the institution asks questions- Did we fail in education, or did we provide inappropriate, little challenging environment? 
The aim of child upbringing is to raise a good person. But the good is understood by each parent, educator and others differently. Understanding of the good is taken primary from educational styles of parents or other close relatives. Secondary, we adapt our good to the standards of our families or wider society. And only tertiary, we take the good from inside of ourselves. And just the last understanding of the good person is the issue of many special and lay discussions. Can heterosexual family guarantee that thanks to its upbringing and environment it can bring up a good and heterosexual person? Or that a homosexual family raise a bad and homosexual person?

\section{Family as a basic social structure of society}

It is almost impossible to define family in exact terms because of different views of several disciplines, aspects (functionality, relationships, roles, religion), etc.

Family, as such, provides a wide range of relationships:

1) cohabitation of biological parents and their children,

2) cohabitation of adoptive or foster parents and adopted children,

3) cohabitation of partners decided not to have children,

4) cohabitation of childless spouses without the possibility of having their own biological children naturally,

5) cohabitation of childless spouses because of so called non-consuming marriage,

6) cohabitation of childless spouses who get their "own" biological child by following ways: artificial insemination of the woman, woman carrying a donated egg, woman who donated an egg to another woman to carry a child but will stand the role of mother after the childbirth.

7) parents who live without their own biological children, as they were unwilling or unable to take care of their children's needs and thus the children were taken away from them,

8) woman who decides to raise the child herself and deliberately does not inform the father

9) gay or lesbian couples taking care of a child of one or both partners.

These alternatives, however, in current rigid Slovak conditions bring many ethical problems. The family is still perceived as an institution to preserve the human race, to cater for the child and its healthy development. We incline, however, to the definition where the family is perceived as a social structure with „democratic" fulfillment of its members' needs. Also J. Prevendárová (2012) states without distinction between heterosexual / homosexual family that the family should be a place of mutual satisfaction of needs, safety, love and certainty. 


\section{So how is it with the homosexuality?}

Questions about the reasons of homosexuality could not be answered so far clearly and satisfactory. There are many various theories of homosexuality and they are based on different disciplines. Some of them support each other, others are in contradiction. Most frequent are following theories (Janošová, 2000):

- theory of genetic disposition,

- theory of impact of development in the prenatal period,

- theory of impact of environment and upbringing,

- theory of seduction.

None of the theories has been clearly confirmed and we believe that the „rightness" of the theory is adjusted by each individual according to subjective criteria which can be, for example, values, attitudes, experiences, etc. Indisputable fact is, however, that homosexuality was removed from the classification of mental diseases and diseases in general. In spite of that, today there are still many professionals working with people (e.g. teachers, educators, doctors) who do not respect that and the Catholic Church does not consider homosexual and heterosexual relationship as equivalent. I. Lukšík (2003) states that the Christian Church itself is not unified on these issues. Homosexuality according to the memorandum of the Evangelical Church in the Rhineland in 1970 states that homosexuality itself is not a perversion, disease, or a sin. It is so only if it is not managed with moral responsibility.

The issue here is not liberalism or strict Catholicism but rather acceptance and tolerance. Sexual minorities currently still face negative attitudes (homophobia). Unlike other phobias homophobia does not mean pathological condition, but rather attitudinal orientation. In extreme forms homophobia may also lead to hate crimes. (Šulová, 2011). The child in the primary environment identifies with homophobic parents, which can later turn into aggression in groups of children. We can talk about the basics of bullying. Non-acceptance of sexual minorities is present in first classes of primary education. The research D. Smetanová (2010) clearly confirmed that different „weak” individuals were exposed to homo bully by children from families where there is strong heterosexism.

Non-acceptance of homosexuals is controlled not only by the family but also by the media. Media present family mostly as a heterosexual marriage/partnership. Homosexuality is shown pathologically, derogatory or with the promiscuous nature.

Clearly weak awareness (by parents or teachers) and non-inclusion of sex education as a compulsory subject in primary schools is considered as one of the negatives aspects.

One of the preventive measures would be if the children and youth were informed in time about their sexual rights. Sexual rights which are defined as basic 
human rights based on fundamental freedom, dignity and equality of all. Since health is an important human right, sexual rights should be also fundamental human rights. In order to ensure development of healthy sexuality of the individual and society it is necessary that all social structures define, support, respect and defend by all means following sexual rights:the right to sexual freedom. This enables individuals to express their full sexual possibilities. It excludes permanently all forms of sexual pressure, exploitation and abuse in all situations of life;

1) the right to sexual autonomy, sexual integrity, and safety of sexual subject. This represents the right to make autonomous decisions regarding his/her sexual life in compliance with his/her personal and social ethics. It also includes control and personal protection from any kind of torture, mutilation and violence;

2) the right to sexual privacy. It includes the right to a personal decision to the extent of intimate behavior unless the rights of others have been violated;

3 ) the right to sexual equality. It points to the freedom from all forms of discrimination, regardless of gender, sexual orientation, age, race, social status, religion or physical or emotional disqualification;

4) the right to sexual pleasure, including autoerotic activities is a source of physical, mental and intellect well-being;

5) the right to express sexual feelings. Sexual expression is more than erotic pleasure from the sexual act. Individuals have a right to express their sexuality through communication, touch, emotional expression and love;

6) the right to sexually associate freely. It expresses the possibility to conclude or not to conclude a marriage, divorce or establish a different type of responsible sexual community;

7) the right to make free and responsible decisions. It includes the right to decide whether or not to have children, number of children, the intervals between their birth, the right to full availability of means regulating fertility;

8) the right to sexual information based on scientific knowledge, which should be open, appropriately spread to members of all social groups;

9) the right to complex sexuality education. It is a lifelong process lasting from birth throughout life and affecting all social institutions;

10) the right to sexual health care. Prevention and treatment of all sexual issues, problems and disorders should be available (L. Śúryová, 2003).

The research D. Smetanová (2010) also clearly showed that there arise relationships of homogeneous nature between girls at first grade of primary school. Among girls, there is a love that can be compared to the partner relationship of „adult world". However, it falls apart and adapt to a stereotypical norms within heterosexual relationships under the influence of the family and the media. The boys were characterized with present passive transposed homophobia, which stopped them from any intimate relationship with individuals of the same sex. 


\section{G/L families and their children}

Postmodernism, on the one hand half-approves coexistence of gays and lesbians, but on the other hand does not accept their legal coexistence. Many countries are responding to the legal relations between persons of the same sex by, so-called, registered partnership, lack of which (also in SR) causes that partners do not have legally settled property relations, do not have health information and so on.

Possibilities of how to bring a child to the family of gays and lesbians:

1) biological mother/biological father-child remains legally live with one of the parents;

2) artificial insemination by donor sperm-anonymous or non-anonymous donor. Use of the clinic services or random acquaintance, friend etc.;

3) surrogacy.

Sedláčková (2009) distinguishes mixed families (parents with children from previous heterosexual relationships) and planned family (parents with children who were planned to be born into a relationship). The author further adds a few attitudes of the society towards homosexual parenting:

1) if the children do not have both mother and father's figure, they will not develop healthily and harmoniously, they will show a lot of mental health problems;

2) these children suffer from rejection of the surrounding due to homophobia in our society;

3) we are adding: the child automatically becomes a homosexual, will be promiscuous, will slow down the economy of the state and so on.

\section{But is the child's arrival into G / L families always true?}

1) full coming-out: lesbians and gays make no secret about their sexual orientation, the arrival of a child is known to the surroundings (family, friends, colleagues);

2) partial coming-out: lesbians and gays keep their orientation secret in front of family, friends. They mostly leave to live away from direct contact with the close ones. They leave the primary family unit and create a fictitious one in gay communities. Arrival of a child to the family is mostly secret or untrue. Threats: the child is confused, intimate communication of parents is different at home and in an environment where their sexual orientation is secret. Child receives orders to conceal information about the family environment, "play the game” acceptable for the environment;

3) the Robinsons: lesbian women and gays live together in secret. The child is de facto hidden. We can talk about the so-called family from a desert island. 
Threats: the child is isolated from its surroundings, peers. After entering the school the child becomes a loner, his social and emotional development is not consistent with its biological age.

Garnerová 2005 (in Sedláčková, 2009) summarized the main concerns of gay parents and the difficulties they face in upbringing:

1) parents may feel that their sexuality is not a matter which should be dealt with children. But a coming-out and the conversation about sexuality and sexual behavior are two different things. To show a child sexual orientation does not necessarily describe sexual activities. Children are not thinking like adults, they do not need to know the details. It is enough to tell them that mom feels affection and love for other women, like other moms feel the love for men;

2) sometimes parents wait until their child is old enough to understand the situation. But at a time when it does not even know what the sexuality is and has not come across homophobic view, the acceptance of its homosexual parents is easier. Children can understand the concept of homosexuality around the age of five, coming-out before puberty is usually accepted with positive reactions. Therefore, it is recommended for the parents to confide to the children as soon as possible. Adolescence is the most difficult period in this respect and such information may be at that moment very stressful;

3) divorcing parents are often afraid that if they confided to the children at the same time with their sexual orientation, it would be too much information at once. But the children tend to construct various reasons of the divorce in their minds and often think they are the reason. Therefore, it is usually relief for many children when they learn the real reason. Moreover, parents who wait until the right moment, risk that the child will learn this information from someone else or in a different way which would be even worse;

4) mothers in planned lesbian families may feel that they were always „out” and do not consider it is important to talk about their homosexuality with the children. Children are probably aware of the difference in their family, but they can be confused with homophobic remarks, which may be heard outside the family, they often do not know how to react. They are not sure whether they can confide with their feelings and experiences to the parents. When parents talk with their children, they give them a vocabulary that the children themselves may use to talk about their family with others and encourage them to mutual conversation;

5) it may take weeks, months but also years until a person put up with his/ her sexual orientation. Also family members must have enough time to be able to process this information. Children may react on the coming-out quite peacefully but also with anger, communication block with parents but also in different way. Negative feelings often change when parents provide enough time and support to the child. 
The issue of G/L families is still open and „tested by fire”. We realize that most of the abovementioned text was and is in favor of the given topic, but in the end we tried to offer a view that is based primarily on the needs of the child. We believe that a child as such is usually lost in this topic, or rather understands it as a maternal or paternal object of ego -desires. The child should, however, be the most concerned subject. Finally, we can ask again the question- Is a child prepared to live nowadays as a child of lesbians and gays? Or is the society just maturing to accept homosexuality? If you answer, yes... that's not enough ...it is not enough for the child to have only loving parents, but it also needs to be accepted not only by his family but also by the wider environment.

\section{Literature}

Helus Z. (2004). Dítě v osobnostním pojetí. Praha Janošová P. (2000). Homosexualita v názorech společnosti. Praha Lukšík I., Supeková M. (2003). Sexualita a rodovost'. Bratislava Prevendárová J. (2012). Rodinná terapia v praxi. Brno

Smetanová D. (2012). Intímna komunikácia v žiackych kluboch. [W:] Kultúra škôl a výchovných zariadení. Bratislava

Sedláčková A. (2009). Specifika dětí z homoparentálních rodin. [W:] 17. Celostátní kongres $k$ sexuální výchově v České republice Sborník referátu. Brno

Šulová L. (2011). Výchova k sexuálně reprodukčnímu zdraví. Praha

Š́ryová L. (2003). Sexuálna výchova ludí so stredným a tažkým mentálnym postihnutím v domovoch sociálnych služieb. Diplomová práca PUK. Bratislava

\section{Alternatywna rola rodziców}

\section{Streszczenie}

Dorota Smetanová w artykule Alternatywna rola rodziców podejmuje problematykę funkcjonowania dzieci wychowywanych w rodzinach gejowskich i lesbijskich (G/L rodziny).

We wstępie stwierdza, że mamy cały czas do czynienia z wpływem instytucji (państwo, Kościół, rodzina), które ograniczają indywidualność i różnorodność styłów życia jednostki. Narzucają one określone ramy społeczne, za których naruszenie spotyka ją kara lub traktowana jest jako patologiczna, chora, niestosownie się zachowująca. Każde naruszenie norm wywołuje pytania w rodzaju: w czym postąpiliśmy nie tak, dlaczego nie udało nam się stworzyć adekwatnego, bardziej pobudzającego środowiska wychowawczego?

Cel wychowania to ukształtowanie dobrego człowieka. Pogląd na temat tego, co znaczy być dobrym człowiekiem, przekazują nam najpierw rodzice, później utożsamiamy się z opinią szerszego społeczeństwa. Dopiero znacznie później jesteśmy w stanie wypracować własne, indywidualne przekonania. I to właśnie wielorakość, pluralizm pojmowania tego, co znaczy być dobrym człowiekiem, stanowi problem. W dyskusjach, także naukowych, pojawiają się pytania: 
czy heteroseksualna rodzina gwarantuje wychowanie dobrego człowieka i czy to jest równoznaczne z wychowaniem osoby heteroseksualnej? Albo - czy rodzina homoseksualna, w której obecne są dzieci, jest równoznaczna ze złym wpływem i kształtowaniemu u dzieci orientacji homoseksualnej?

Autorka podkreśla, że rodzina jest zazwyczaj rozumiana jako instytucja gwarantująca przedłużenie gatunku, zapewniająca zaspokojenie potrzeb dzieci i ich prawidłowy rozwój. Sama jednak skłania się ku definicji postrzegające rodzinę przede wszystkim jako strukturę społeczną, w której w sposób „demokratyczny” realizowane są potrzeby wszystkich jej członków.

Autorka stwierdza, że nie ma jednoznacznych wskazań co do powstawania orientacji homoseksualnej u jednostki, istnieją różnorodne hipotezy na ten temat, lecz żadna z nich nie została naukowo potwierdzona. Bezspornym faktem jest, że homoseksualizm został usunięty z klasyfikacji chorób psychicznych i chorób w ogóle. Mimo to wciąż istnieje wielu specjalistów (wśród nich znajdują się nauczyciele, wychowawcy, lekarze) nie przyjmujących tego faktu do wiadomości. Kościół katolicki nie uważa relacji homoseksualnej za równoważną relacji heteroseksualnej. Zdaniem Autorki problem polega nie na wyznawanych wartościach, lecz raczej na akceptacji i tolerancji.

Mniejszości seksualne są nieustająco narażone na negatywne reakcje ze strony różnych osób (homofobia). Także media w większości utrwalają obraz małżeństwa/partnerstwa jako relacji wyłącznie heteroseksualnej, a osoby homoseksualne często przedstawiane są przez media w sposób ośmieszający lub jako osoby chore lub o wybujałej seksualności. Do niskiego poziomu świadomości na ten temat przyczynia się także brak obowiązkowej edukacji seksualnej w szkołach podstawowych na Słowacji. Dzieci i młodzież powinny być informowane o swoich seksualnych prawach. Jako składnik zdrowia, które należy do podstawowych chronionych wartości, również seksualność i prawa z nią związane powinny być chronione. Rozwój zdrowej seksualności powinien być przedmiotem troski wszystkich instytucji społecznych.

W wielu państwach istnieją prawnie usakcjonowane związki partnerskie pomiędzy osobami tej samej płci. Autorka podkreśla, że brak prawnej regulacji skutkuje gorszą pozycją osób o orientacji homoseksualnej.

Jednak problematyka G/L rodzin, zdaniem autorki, jest wciąż otwarta - „wykuwana w ogniu“. W małym stopniu w dyskusjach na ten temat uwzględniane są potrzeby dziecka. Dziecko często traktowane jest li tylko jako przedmiot egoistycznych pragnień rodziców. A przecież dziecko powinno być podmiotem sytuacji, która go dotyczy.

W konkluzji autorka stawia pytanie: czy w dzisiejszym społeczestwie jest miejsce dla dzieci gejów i lesbijek? Istotność tego pytania polega na tym, iż dziecku nie wystarczają kochający rodzice, lecz potrzebuje także akceptacji szerzego środowiska. 